\title{
Modeling the risks process, associated with the violation of rolling stock operation
}

\author{
Victoriya Lyashenko* (iD), Aleksey Muratov in
}

Samara State Transport University. Samara, Russia

\begin{abstract}
The article analyzes a possible approach to the construction of a risk management model at the enterprises of the locomotive complex of JSC "Russian Railways" performing rolling stock operation. The suggested model can be implemented in a system for organizing the safety of rolling stock operation. The relevance of improving safety is particularly acute when operating high-tech rolling stock with a high complexity of control algorithms. The objetive is the analysis and development of solutions to improve operational efficiency using a model that provides solutions to the problems of choosing optimal and safe operating modes from the point of view of implementing rolling stock management processes. Reducing the number of violations during the operation of rolling stock can be realized with the active use of a risk-based model that takes into account the possibility of predicting factors that affect the occurrence of risks. In this regard, the issues related to the implementation of risk management in operational locomotive depots are considered. The most rational approach to the implementation of risk management for a variety of uncontrolled factors that have a significant impact on the safety and accident-free operation is given. A model for solving multi-criteria problems is suggested as one of the options for choosing the safe operation of rolling stock.
\end{abstract}

Keywords: risk function; risk management; rolling stock operation.

\section{Modelación del proceso de riesgos, asociado a la violación de la operación de material rodante}

Resumen.- El artículo analiza un posible enfoque para la construcción de un modelo de gestión de riesgos en las empresas del complejo de locomotoras de JSC "Ferrocarriles de Rusia" que realizan la operación de material rodante. El modelo sugerido puede implementarse en un sistema de organización de la seguridad de la explotación del material rodante. La importancia de mejorar la seguridad es especialmente importante cuando se opera con material rodante de alta tecnología con una alta complejidad de algoritmos de control. El objetivo es el análisis y el desarrollo de soluciones para mejorar la eficacia de la explotación mediante un modelo que aporte soluciones a los problemas de elección de modos de explotación óptimos y seguros desde el punto de vista de la aplicación de los procesos de gestión del material rodante. La reducción del número de infracciones durante el funcionamiento del material rodante puede realizarse con el uso activo de un modelo basado en el riesgo que tenga en cuenta la posibilidad de predecir los factores que afectan a la aparición de riesgos. A este respecto, se examinan las cuestiones relacionadas con la aplicación de la gestión de riesgos en los depósitos de locomotoras en funcionamiento. Se ofrece el enfoque más racional para la aplicación de la gestión de riesgos para una variedad de factores no controlados que tienen un impacto significativo en la seguridad y el funcionamiento sin accidentes. Se sugiere un modelo de resolución de problemas multicriterio como una de las opciones para elegir la operación segura del material rodante.

Palabras clave: Función de riesgo; Gestión de riesgos; operación de material rodante.

Received: October 25, 2021.

Accepted: November 29, 2021.

* Correspondence author:

e-mail.1yashenko@samgups.ru(V. Lyashenko)

\section{Introduction}

A comprehensive study of the professional activities of locomotive crews is based on a combination of knowledge of such sciences as psychology and physiology, which allow to determine the optimal human behavior in order to ensure the safety of rolling stock operation. On railway transport, the duties of employees 
are clearly regulated, aimed at ensuring the transportation process with maximum safety of the rolling stock movement. The main responsibility of railway transport workers is to ensure the transportation process with the unconditional safety of train traffic [1].

The existing organization of rolling stock operation is based not only on traffic safety, but also on the principle of JSC "Russian Railways" customer oriented approach. In order to improve the production, economic and other priority areas of scientific, technological and innovative development of the Russian Railways holding, the development of risk management methods related to the safety and reliability of the transportation process was noted in the Strategy of Scientific and Technological Development of the Russian Railways Holding until 2025 and for the future until 2030.

Guided by the set of rules for modeling business architecture and business processes, approved by the order of JSC "Russian Railways" according to the description of the risk classification, one of the key internal technological risks is a decrease in traffic safety due to a decrease in the reliability of rolling stock. Violation of the rules of rolling stock operation is one of the main reasons for reducing the reliability of rolling stock and, as a result, reducing traffic safety [2, 3].

Therefore, in all structural divisions, including enterprises of the locomotive complex that implement the process of rolling stock operation, documents regulating work in accordance with the requirements of the ISO 9000 standards family, aimed at building organizational work using the principles and methods of the quality management system, were developed and are constantly updated [4, 5, 6].

\section{Methods}

Consistent and structured activities aimed at eliminating possible risks are called risk management, which is integrated into the overall quality management system of the organization.To build a risk management system in the structural divisions of the locomotive complex serving the rolling stock, we use the S-step algorithm [7, 8]. Based on this algorithm, we will develop an example of its implementation to manage the risks associated with the efficiency of rolling stock operation.

The proposed algorithm includes a number of sequential stages, the implementation of which will allow to develop a number of effective measures to eliminate and prevent factors that affect the occurrence of risk. At the first stage, the main causes of errors in the operation of rolling stock by locomotive crews are determined, and their ranking is carried out. At this stage, it is very important to conduct a comprehensive analysis that will help to focus on the limiting errors that are most common during operation. The second stage is the selection of a group of experts whose competencies will allow to effectively group and identify risks, as well as accurately determine the causes of their occurrence. For our case we have selected experts according to the following criteria:

- specialists in the organization of the processes of maintenance and operation of rolling stock (chief engineers of regional directorates, heads of technical departments of regional directorates, etc.);

- specialists of rolling stock manufacturing plants;

- specialists of personnel services of structural divisions of the locomotive complex.

The following main criteria are used to assess the competence of experts and their selection:

- availability of specialized education and its level, qualification;

- work experience in this field;

- the results of the questionnaire/testing to establish the objectivity and effectiveness of the expert.

The quantitative composition of the expert group is determined by the administrative act of the head of the regional directorate of traction, depending 
rules by locomotive crews. It was revealed, that due to illiterate actions the following main events occurred:

- violations of the train driving mode,

- locomotive malfunction,

- poor quality acceptance,

- flat spots,

- passage,

- derailing,

- collision,

- unauthorized movement of railway rolling stock.

It is obvious that the illiteracy of locomotive crews, which leads to a violation of traffic safety and operating rules, is associated with certain risk factors. Therefore, the next step in the implementation of the proposed model is to determine the risk factors. In the traction directorates at this stage the following indicators are usually used as such factors with regard to the activity of locomotive crews:

1. percentage of locomotive crews understaffing,

2. percentage of staff turnover,

3. percentage of non-fulfillment of the advanced training plan by locomotive crews,

4. percentage of employee dismissals,

5. percentage of employees with less than 1 year of work experience.

As we can see, most of these factors are related to the qualification of the personnel of locomotive crews and the quality of labor organization. The most significant indicator in the assessment of risk factors is the percentage of staff turnover, the number of workers with less than 1 year of experience.

Also, overtime work is not an unimportant factor affecting the safety of the operation of rolling stock by locomotive crews. The main reasons for the allowed hours of overtime work are:

- lack of the number of locomotive crews, for the amount of work performed, taking into account the actual costs per one trip;

- distraction of locomotive crews.

- non-compliance with running standards and locomotive crews turnover standards;

- failures of technical means.

This circumstance has a significant impact on 


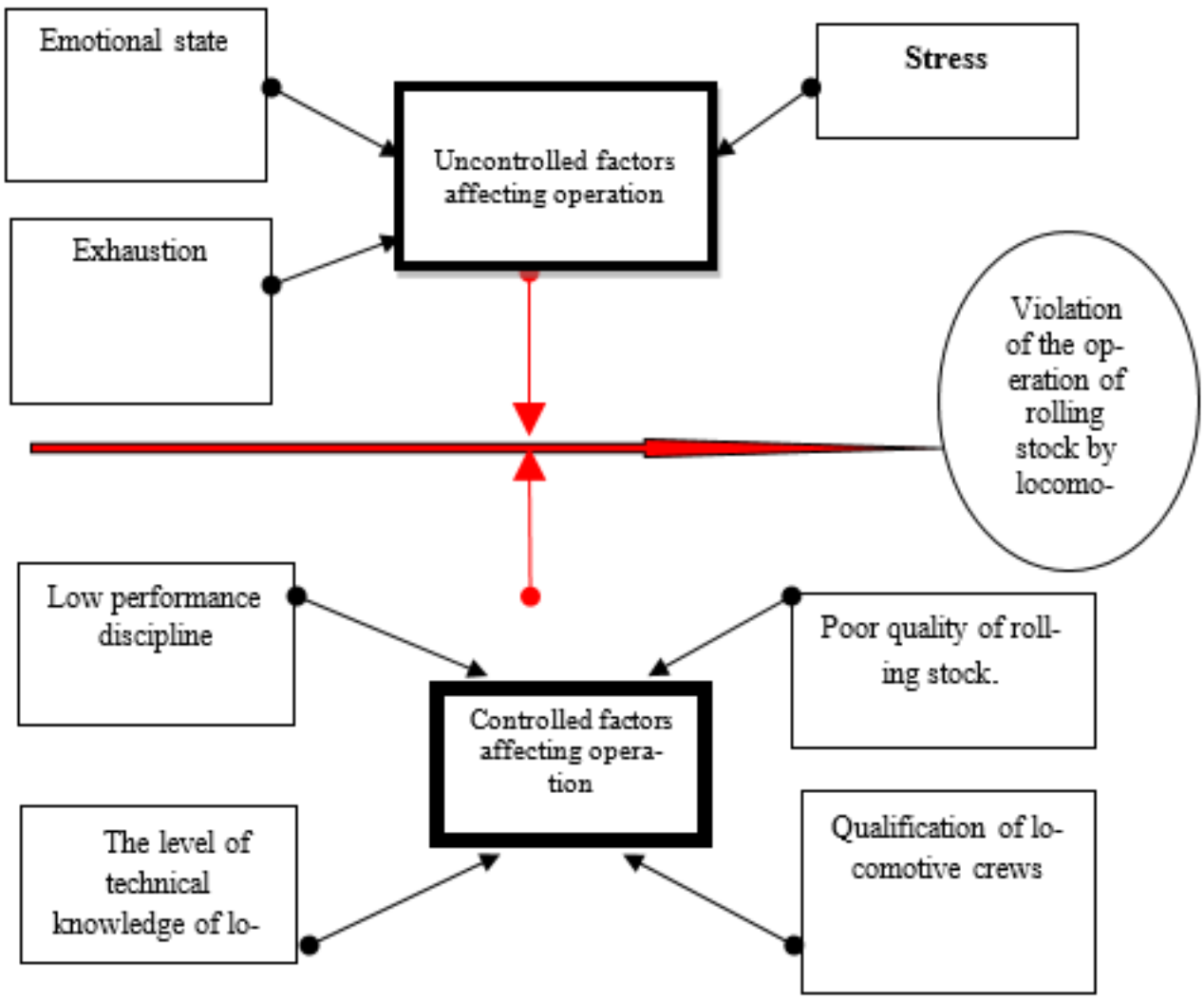

Figure 1: Diagram of causal relationships (of Ishikawa) of factors affecting the violation of the operation of rolling stock locomotive crews

the emergence of new risk factors associated with human physiology. The reasons described above can be combined into a generalized reason - the human factor. As can be seen from the analysis, the main risk factor is errors in the course of professional activity. And if such factors that affect safety as errors related to ignorance of regulations, rules, careless attitude to their duties, inexperience, incompetence can be attributed to controlled factors. Then such factors as fatigue, exhaustion, emotional state, stress belong to uncontrolled factors-uncertainties [9, 10].

Based on the conducted factor analysis and the identified reasons for violations of technical operation of rolling stock rules, it is clear that the availability of a set of statistical data is not sufficient to determine possible risks. Therefore, in relation to structural divisions for the operation of rolling stock, the concept of risk can be considered as a deviation of any values from the expected meanings [11].
In addition, the analysis shows the existence of uncertainties - uncontrolled factors that can directly affect the safe operation of rolling stock and lead to the possibility of deviation of any parameters from their required values, i.e. risks. All of the above factors have a significant impact on professional ability to work, i.e., the maximum possible productivity. The analysis of rules violations cases of rolling stock operation and traffic safety in order to identify the main factors allowed us to form a diagram of cause-and-effect relationships (Figure 11). The data obtained can be used as the basis for the risk management model being developed, however, it is impossible not to take into account the so-called uncontrolled factors, which are very often the cause of violations of the rules of rolling stock operation by locomotive crews.

The risk based on uncontrolled factors will be characterized by a random value $R$, depending on the random values $x$ and $y$, which determine the 
emotional and physical state of a person, then the average value $R_{0}$ of the value $R$ does not fully describe the situation. The total risk in a certain series $n$ is estimated by an average value by equation (1) [12, 13]:

$$
R(n)=1 / n \cdot\left(R_{1}+R_{2}+R_{3}+\cdots+R_{n}\right)
$$

where $n$ are random variables $R_{1}, R_{2}, R_{3}, \cdots, R_{n}$ These values are independent and distributed in the same way as $R$, and with an unlimited increase, it stabilizes near $R_{0}$ - the average value .

Let's assume that to find the risk associated with the emotional and physical state of a person, it is necessary to take into account the following criteria:

- the ability of the relevant official to make decisions based on information about the employees of this locomotive crew and the implementation of certain actions based on it,

- analysis of a large amount of information, which can include the physiological parameters obtained at the medical examination, work schedule, psychological type of a person, relationships in the locomotive crew - many uncertainties,

- a criteria-based approach that allows to evaluate the effectiveness and correctness of the decision made by an official.

Given these three criteria, we can find the risk criterion.

The solution of this problem can be written as the following mathematical expression [14]:

$$
\langle X, Y, f(x, y)\rangle,
$$

where $x$ is the chosen alternative in the range of the set $X \subseteq R^{n}$, chosen by the responsible official.

The main goal is to select $x \in X$ for which the scalar criterion $f(x, y)$ reaches the largest possible value. In this case, it is necessary to take into account the action of a large number of different types of uncertainties $y$, the classification of which is given above, about which it is only known that they take a value from a given set $Y \subseteq R^{m}$.
The total risk associated with the emotional and physical state of the locomotive crew employee is calculated according to the dependence (11). To make the most correct decision, you can use the appropriate weight coefficients for each risk, reflecting its impact and determined by the method of expert assessments.

\section{Conclusion}

Using the proposed risk management model, it is possible to formulate a number of general measures to reduce the impact of negative factors on traffic safety, such as:

- development of an individual approach to conducting pre-trip training of locomotive crews,

- advanced training of drivers-instructors,

- preventive work on checking the knowledge of rolling stock management, instructions, organization of unscheduled inspections based on the results of factor analysis, etc.

However, as a comprehensive analysis showed, it is necessary to take into account negative factors such as fatigue, exhaustion, and emotional state when making management decisions on the risks associated with the violation of the operation of traction rolling stock by locomotive crews. The solutions to these problems are in different areas of scientific knowledge, so the development of a generalized model and the stages of modeling will reduce the impact of these negative factors on the safety of rolling stock operation by locomotive crews.

\section{References}

[1] E. Leonova, O. Lukovtseva, and I. Mironova, "Professionally important qualities of locomotive team employees of jsc rzd," Bulletin of Kaluga Unibersity. Psychological Sciences. Pedagogical Sciences, vol. 3, no. 2(7), pp. 29-33, 2020.

[2] JSC, "Functional quality management strategy, approved by Order No. 46 r of January 15, 2007," JSC Russian Railways, Tech. Rep., 2007. 
Lenand, 2011.

[3] JSC, "Quality management strategy in the Russian Railways holding," JSC Russian Railways, Tech. Rep., 2016.

[4] D. Antipov, E. Kuznetsova, and A. Aytasova, "Digital technologies and QMS of industrial enterprise: Focus on efficiency," in IOP Conference Series: Materials Science and Engineering, ser. 012024, vol. 986, no. 1, 2020. https://doi.org/10.1088/1757-899X/986/1/ 012024

[5] A. Muratov, V. Lyashenko, and S. Petukhov, "QMS as tool for improving maintenance and repair processes of traction rolling stock." in 5th International Conference on Industrial Engineering (ICIE 2019), Lecture Notes in Mechanical Engineering, A. Radionov, O. Kravchenko, V. Guzeev, and Y. Rozhdestvenskiy, Eds., vol. 2. Cham, Switzerland: Springer, 2020, pp. 411-418. https://doi.org/10.1007/978-3-030-22063-1_44

[6] Y. Palchun, V. Serikh, I. Yakimova, and I. Kvitkova, "Thegeneralized analysis of parameters measurement of processes in QMS." in 2012 IEEE 11 th International conference on actual problems of electronic instrument engineering, vol. 1. IEEE, 2012, pp. 99-100. https: //doi.org/10.1109/APEIE.2012.6629150

[7] T. Aleksandrova and V. Novikova, "Risk management technique for the QMS processes at the university," in IOP Conference Series: Materials Science and Engineering, ser. 012045, vol. 666, no. 1, 2019. https: //doi.org/10.1088/1757-899X/666/1/012045

[8] S. Valdokhina, "Analysis of methodological approaches to assessing the effectiveness of the quality management system (QMS)," in IOP Conference Series: Earth and Environmental Science, vol. 341, no. 012221, 2019.

[9] A. Rezchikov, O. Dolinina, V. Kushnikov, V. Ivaschenko, K. Kachur, A. Bogomolov, and L. Filimonyuk, "The problem of a human factor in aviation transport systems," Indian Journal of Science \& Technology, vol. 9, no. 46, pp. 16-20, 2016. https://doi.org/10.17485/ijst/2016/v9i46/107351

[10] K. Tuminas and T. Sennikova, "Effective technology to reduce human-factor ricks on public transport," Public Transport International, vol. 55, no. 20, pp. 18-20, 2006.

[11] G. Barinova and L. Astashkina, "Human factor on the railway transport: Safety problems," Science and Technology in Transport, vol. 2017, no. 1, pp. 84-87, 2017.

[12] E. Mikhailova, M. Mikhaylov, and S. Stazhkov, "Investigation of risk management problems when constructing of the QMS processes," in International DAAAM Symposium "Intelligent manufacturing and automation: Power of knowledge and creativity, B. Katalinic, Ed., vol. 22, no. 1. Vienna: Danube Adria Association for Automation and Manufacturing, 2011, pp. 1385-1386. https://doi.org/10.2507/22nd. daaam.proceedings.677

[13] V. Zhukovsky, Risks in conflict situations. Moscow:
[14] E. Mushik and P. Muller, Methods of making technical decisions. Mir Publishers, 1990. 